ORIGINS OF CONTAINMENT 



\section{Origins of Containment}

A Psychological Explanation

By Deborah Welch Larson

PRINCETON UNIVERSITY PRESS

PRINCETON, NEW JERSEY 
Copyright @ 1985 by Princeton University Press

Published by Princeton University Press, 41 William Street,

Princeton, New Jersey 08540

In the United Kingdom: Princeton University Press, Chichester, West Sussex

All Rights Reserved

\section{Library of Congress Cataloging-in-Publication Data}

Larson, Deborah Welch, 1951-

Origins of containment.

Bibliography: $p$.

Includes index.

1. United States - Foreign relations-Soviet Union-Psychological aspects. 2. Soviet Union-Foreign relations-United States-Psychological aspects. 3. United StatesForeign relations-1945-1953-Psychological aspects. I. Title: Containment : a psychological explanation.

E183.8.S65L36 $\quad 1985 \quad 327.73047 \quad 85-42691$

ISBN 0-691-07691-X

ISBN 0-691-02303-4 (pbk.)

Publication of this book has been aided by a grant from the Whitney Darrow fund of Princeton University Press

This book has been composed in Linotron Galliard

Princeton University Press books are printed on acid-fiee paper and meet the guidelines for permanence and durability of the Committec on Production Guidelines for Book Longevity of the Council on Library Resources

http://pup.princeton.edu

Printed in the United States of America

$\begin{array}{lllllll}10 & 9 & 8 & 7 & 6 & 5 & 4\end{array}$ 
To David 
